\title{
はばたき水車の試み*
}

岩岸 知崇*1, 中村尚彦苂, 本村真治 ${ }^{* 2}$, 中川 幸二*2

\section{A Trial of Flapping Water Turbine}

\author{
Chiso IWAGISHI"1 ${ }^{*}$, Takahiko NAKAMURA, Shinji HONMURA and Koji NAKAGAWA \\ ${ }^{* 1}$ Hakodate National College of Technology. Advanced Course of Production System Engineering \\ Tokura 14-1, Hakodate, Hokkaido, 042-8501Japan
}

\begin{abstract}
A flapping water turbine is a kind of power generating machine which extracts mechanical energy from flowing water by swing of blade motion. In this study, we carried out numerical simulation of blade motion and experiment on river. In the simulation, we made numerical integration of momentum equation about roll angle and compared the result with experiment in water channel. The disagreement in roll angle between the simulation and the result of experiment were discussed by using analytical model and basic data of blade fluid dynamic characteristics. The result of river experiment showed that flapping water turbine can extract energy from stream with rippling surface and turbulence.
\end{abstract}

Key Words : Water Turbine, Blade, Fluid Dynamics, Wave, Numerical Simulation

\section{1. はじめに}

羽根の往復運動により, 水の流れから動力を取り出寸方法がいくつか提案されている. 前後の 2 枚の羽根をリ ンク機構で支持して水路に設置し, ピッチングと上下運動の繰り返しによる方法で動力取り出しを実施した例 ${ }^{(1)}$, 片持ち梁のように羽根を支持してヨーイング（縦軸型の場合），ピッチング（横軸型の場合）を周期的に変化させ て羽根を往復運動させる方法(2)が提案され実験結果が報告されている. これらの方法は, ダムやせきで流れをせ き止めないので環境に与える影響が少ないと考えられる. しかし, 羽根を支持しつつ, 往復運動の始点と終点で 角度を変化させる複雑な機構が必要で, 実用化を目指寸場合に信頼性の確保が大きな課題となるであろう.

本報告は, 水流方向の軸回りに往復回転運動する羽根で動力を取り出し, 往復運動の始点と終点では, 重力を 利用して角度を変化させる簡単な機構を備えた「はばたき水車」を提案するものである. 往復運動する羽根を用 いているので「水車」の語を用いるのはふさわしくないが，直観的な理解を期待して「はばたき水車」と呼ぶこ ととする．なお風力についても羽根のピッチ角を変化させ羽ばたき運動によって動力を取り出す方法 ${ }^{(3)}$ が提案さ れているが，実験結果は記載されていない.

これまで, 回流水槽を用いて流速が毎秒 0.3 メートル程度の実験により水車の動作, 装置構成などの基礎的 な研究を行ってきた ${ }^{(4)(5)}$. また, 装置の各設定值の変更による出力, 周期の測定などの実験的な研究に加え, 時間 を変数とする一次元解析を実施し各パラメータの変化ごとの出力トルクの予測を試みてきた ${ }^{(6)}$.

本報告では, 一次元解析の值と実験結果の一致度の改良と, 波などの水面位置の変化と断面流速が一様でない 河川で，はばたき水車が作動できるかを実験により調べた結果を述べる.

\section{2. はばたき水車}

図 1 にはばたき水車の基本構成図を示寸.はばたき水車の主な構成は流れから往復運動をして出力を取り出す

\footnotetext{
* 原稿受付 2011 年 3 月 8 日

*1 学生員, 函館工業高等専門学校専攻科生産システム工学専攻

*2 正員，函館工業高等専門学校（一042-8501 北海道函館市戸倉町 14 番 1 号)

E-mail: hnctnaga15@yahoo.co.jp
} 
ための “羽根”，出力軸の上側と下側の質量をつりあわせるための “カウンターウエイト”，出力を取り出すため の “出力軸”, “羽根支持軸” である. 羽根全体が水上に露出した状態でつりあうとはばたき運動が継続できなく なる. このためカウンターウエイトの質量は空気中でロール角を与えて羽根がゆっくり真下に移動しで静止する 程度にした. 羽根支持軸は羽根を支持し, 水流に対してヨー方向の自由度を持つよう軸受内蔵ケーシングにより 回転可動に支持されている．軸受はすべて大気中にあり潤滑，封水装置といった複雑な部品を必要としないのが 特徵である. 図 2 で羽根のヨ一角反転の過程を説明する. 羽根が運動してロール角が大きくなると次第に羽根が 水から露出寸る部分が多くなり, 羽根が発生する揚力が小さくなる.さらに羽根にかかる浮力も減少する.また, 羽根支持軸の中心は羽根の重心とオフセットさせてあり, 羽根の発生する流体力のモーメントが羽根の質量にか かる重力のモーメントより小さくなったときに反転がスタートする. ヨー角が反転するとロール運動の方向が反 転する.この動作を繰り返し往復運動ができる.

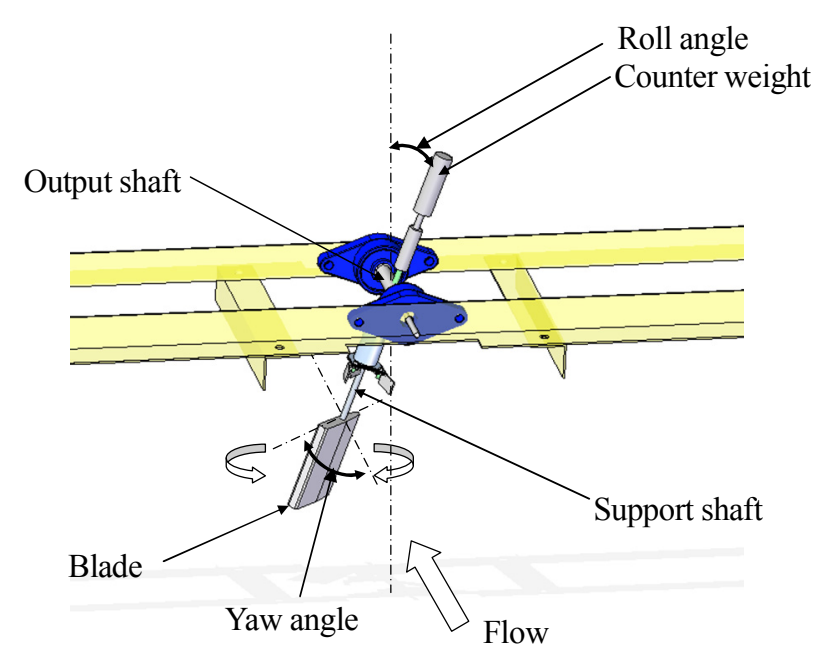

Fig.1 Flapping water turbine

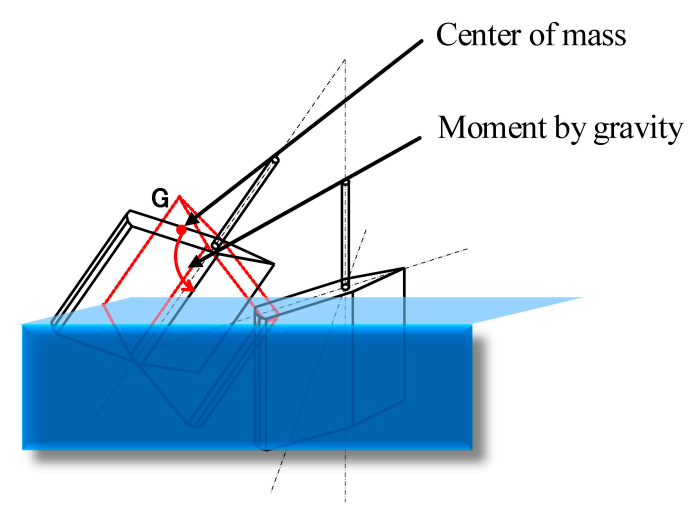

Fig.2 Process of blade turning

\section{3. 水槽実験}

図 3 に回流水槽で実験した装置を示す．解析で求めた出力と比較するためヨー角を変化させて最大ロール角 $\Delta$ $\phi$, トルク $T, 5$ 往復の周期 $t_{5}$ の測定をおこなった.

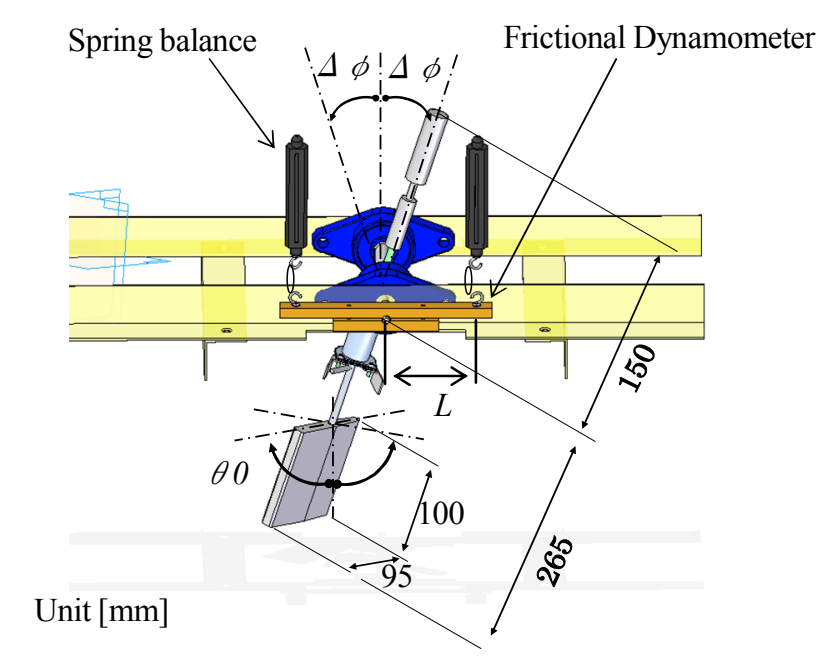

Fig.3 Apparatus of experiment

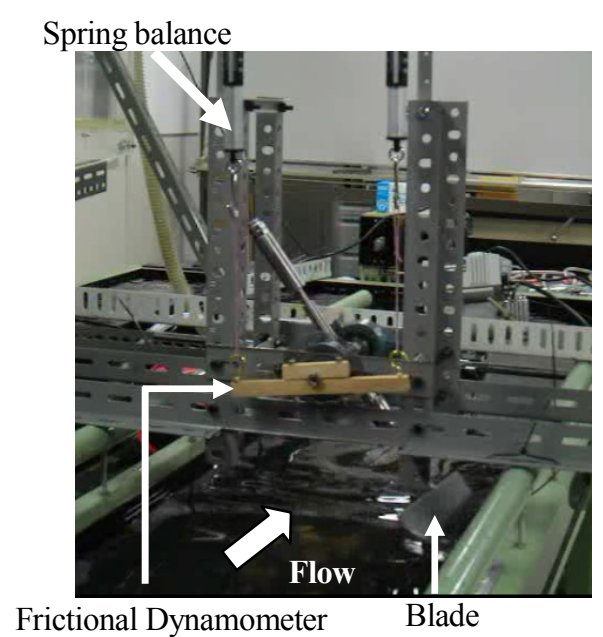

Fig.4 Experiment in water channel 
トルクは図 3 に示寸ように摩擦動力計によって制動をかけ，左右のばね秤によって往復運動中の力の最大值と 最小值を読取って測定した. 動力計は図 4 に示すように出力軸(直径 $6 \mathrm{~mm}$ )を 2 本の木片で挟み, ビスで挟む力を 調整する簡易な構成のため, 微妙な調節が困難であった. このため各設定ヨー角 $\theta_{0}$ ごとに羽根の継続的往復運動 が可能な範囲で，もっとも大きな出力トルク $T$ が得られるよう調節した. 実験中の流速 $U$ は $0.27[\mathrm{~m} / \mathrm{s}]$ で，水面 にトレーサを浮かべ指定距離 $(1 \mathrm{~m})$ を移動する時間を測定することにより求めた. また，ロール角の測定は分度器 を用いて運動中の左右のロール角最大值 $\Delta \phi$ を読んだ. 測定は設定ヨー角 $\theta_{0}$ を 0.74[rad $](42.5[\mathrm{deg}]), 0.65[\mathrm{rad}]$ (37. $5[\mathrm{deg}]) ， 0.48[\mathrm{rad}](27.5[\mathrm{deg}])$ の 3 種類に変化させた. 羽根 5 往復に要する時間 $t_{5}$ はストップウォッチを 用いて測定した。図 4 に実験の様子を示す.

式(1)にトルク算出の式を示す. 式中の $F_{R H}, F_{L L}$ ，はそれぞれロール運動が図 4 に向かって時計方向に運動した ときの右側の秤の最大值と左側の秤の最小值，また $F_{L H}, F_{R L}$ は反時計方向に運動したときの左側の秤の最大值と 右側の秤の最小值である. また $L$ は摩擦動力計の腕の長さである.

$T=\frac{1}{2} \times\left\{\left(F_{R H}-F_{L L}\right)+\left(F_{L H}-F_{R L}\right)\right\} \times L$

表 1 に実験の結果を示す， $\theta_{0}$ を $0.48 \sim 0.74$ に変化させても $\Delta \phi$ の変化は少ないが， 平均ロール角速度 $\omega_{m}$ とトルク $T$ は変化が大きい. $\theta_{\sigma}=0.65$ で $T$ が最大值をとることについては以下の二点を原因として推定し ている．第一は 0.74 では $\theta_{0}$ が過大で，羽根の迎え角が最適值を超えてしまったとすることである. 第二は 反転過程にかかわるものである. 羽根が反転して真下にいたる間は羽根角度を，。で急停止させたことによ る衝撃力と水中にある羽根面積が増加することによる流体力の増加の両方で大きなトルクが発生するが， 羽根が真下から反転するまでは羽根が水面に出ている面積が大きくなり流体力が減少するとともに, 羽根 の一部を水面上に持ち上げるための力が必要になるためトルクが減少する. $\theta \bar{\sigma} 0.74$ ではこの減少分が大 きいと考えられる.これらの推定を確認寸るためには, トルクとロール角の瞬時值の測定が必要であり, 本 研究では実施していないので推定にとどめる.

Table 1 Result of experiment

\begin{tabular}{c|c|c|c|c|c}
\hline $\begin{array}{c}\text { Flow velocity } \\
{[\mathrm{m} / \mathrm{s}]}\end{array}$ & $\begin{array}{c}\theta_{0} \\
\text { Set yaw angle } \\
{[\mathrm{rad}]}\end{array}$ & $\begin{array}{c}\Delta \phi \\
\text { Roll angle } \\
{[\mathrm{rad}]}\end{array}$ & $\begin{array}{c}t_{5} \\
\text { Time of five cycle } \\
{[\mathrm{s}]}\end{array}$ & $\begin{array}{c}T \\
\text { Torque } \\
{[\mathrm{N} \cdot \mathrm{m}]}\end{array}$ & $\begin{array}{c}\omega_{m}=2 \Delta \phi /\left(t_{5} / 5\right) \\
\text { Mean roll angler velocity } \\
{[\mathrm{rad} / \mathrm{s}]}\end{array}$ \\
\hline \multirow{3}{*}{0.27} & 0.74 & 0.567 & 18.5 & 0.0058 & 0.306 \\
\cline { 2 - 6 } & 0.65 & 0.524 & 24.2 & 0.018 & 0.217 \\
\cline { 2 - 6 } & 0.48 & 0.48 & 33 & 0.0062 & 0.145 \\
\hline
\end{tabular}

\section{$4 \cdot 1$ ロール角に関する運動方程式}

\section{4. 解析による出力予測}

はばたき水車が動作することは実験により確認できたが，運動の機構と出力を支配するパラメータの検討を目 指して解析による出力予測を試みた．解析には沉用数式処理ソフト Mathematica Ver. 5.2 を用いた. 出力軸のロー ル角 $\phi$ に関寸る運動方程式を導き，ロール角 $\phi$, 角速度 $d \phi / d t$ および出力トルクについて予測をおこない回流水 槽での実験值と比較することによって精度の評価をおこなう。本報告では初期の解析( ${ }^{(6)} ヨ コ 一$ 角の反転と運動中 の羽根面積に関し改良をおこなった．式(2)に時間 $t$ を独立変数とするロール角 $\phi に$ 関する二階常微分方程式を示 す. 
$I \frac{d^{2} \phi}{d t^{2}}=r\left\{\frac{1}{2} \rho \cdot S \cdot V^{2} \cdot C \cdot \operatorname{Sign}\left(\frac{d \phi}{d t}\right)-g \cdot \Delta m \cdot \sin (\phi)\right\}-T$

左辺は出力軸周りの慣性モーメント $I\left(0.008 \mathrm{~kg} \cdot \mathrm{m}^{2}\right)$ と角加速度の積である. 右辺の中括弧内の第一項目は羽根 が発生する揚力, 第二項目は出力軸中心より上のカウンターウエイト側の質量と出力軸中心より下側の羽根構成 部の質量の差が重力により発生するモーメントが出力軸から $r($ 式(3) )だけ離れたところにあるとして表わした アンバランス質量 $\Delta m$ を用いてロールの進行方向と逆方向の力を表している. $g$ は重力加速度 $\left(9.8 \mathrm{~m} / \mathrm{s}^{2}\right)$ である. 式 (2)中の Sign は Mathmatica 特有の関数で括弧内の式が正ならば+1，負ならば-1 を出力する.これは運動方向の符 号を装置正面から見たときロール方向は時計回りを正，反時計回りを負とし，ヨー角の符号はロールが正方向に 運動しているときのヨー角を正，負方向に運動しているときを負とするためである．また出力軸から取出される トルクを $T$ としている.

中括弧第一項目の羽根が発生する流体力は水の密度 $\rho\left(1000 \mathrm{~kg} / \mathrm{m}^{3}\right)$, 水中の羽根面積 $S$, 相対速度 $V$, 流体力係 数 $C$ で表される. 羽根面積 $S$ は式(4)で求める. 式(4)中の記号の意味は図 5 に示す.
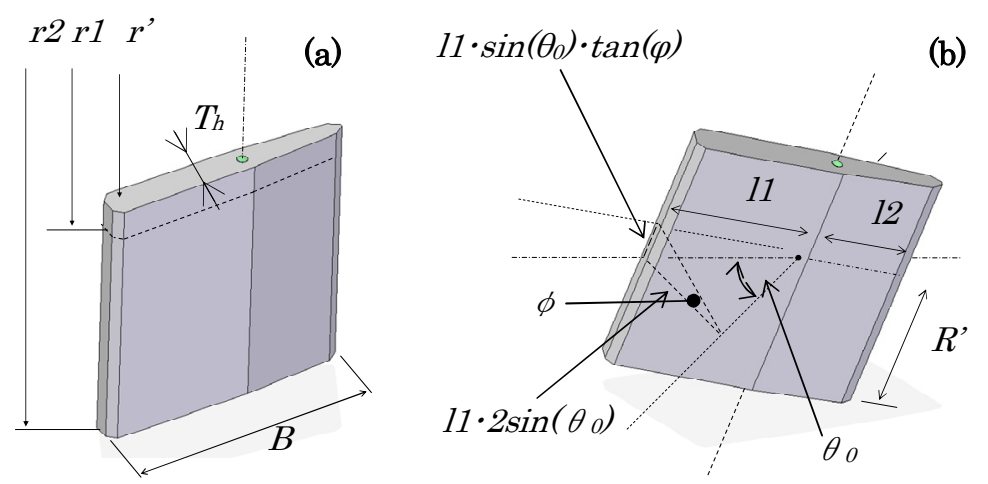

Water level

$\theta_{0}$ : Set yaw angle

$11=0.055[\mathrm{~m}]$

$12=0.04[\mathrm{~m}]$

Fig.5 Blade area in water

$r$ は式(3)により定義する.

$r=\frac{1}{2}\left(r_{2}+\frac{r_{1}}{\cos \phi}\right)$

$S=\left\{R^{\prime}+\frac{1}{2} \sin \left(\theta_{0}\right) \cdot \tan (\phi) \cdot\left(l_{2}-l_{1}\right)\right\} \cdot B$

ここに $R^{\prime}=r_{2}-\frac{r_{1}}{\cos (\phi)}$ である.

運動中の羽根への相対流入速度 $V$ は流速 $U$ と羽根周速度 $r \cdot d \phi / d t$ により

$V=\sqrt{U^{2}+\left(r \frac{d \phi}{d t}\right)^{2}}$

によって定義する. また, 羽根の流体力係数を表す $C$ は発生する揚力の余弦成分と抗力の正弦成分により 
$C=\left(C_{L} \cos \alpha-C_{D}|\sin \alpha|\right)$

で求める. このとき $\alpha$ は流速 $U$ と羽根周速度 $r \cdot d \phi / d t$ とのな寸角である. 抗力は常にロール運動と逆方法に働く ため式中の $\sin \alpha$ は絶対值をとっている. 角度, 速度の関係を図 6 に示寸.

出力軸から取出される出力トルク $T$ は式(7)のようにトルク係数 $T_{\text {con }}$ とロール角速度 $d \phi / d t$ の積で表した.

$$
T=T_{c o n} \cdot \frac{d \phi}{d t}
$$
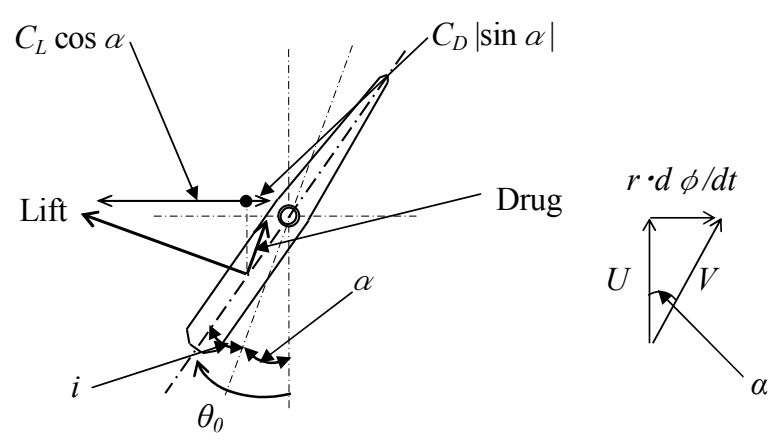

Fig.6 Relative velocity and direction of fluid dynamic force

\section{$4 \cdot 2$ 羽根の流体力学的特性}

羽根の揚力特性は入射角 $i$ (図 6)により変化する. 図 7 に羽根の揚力・抗力特性を示す. 用いた羽根は NACA0012 と形状が似ていることから NACA0012 の特性 (7) を基本とした多項式とした. 図中にある揚力係数 $C_{L}$ は翼幅が十 分長い場合の揚力特性として求められたものであり，有限翼幅かつ水面という自由表面をもつはばたき水車の $C_{L}$ ではなんらかの補正が必要である. 寸なわち羽根の水中の先端側では翼端渦の影響があり, 水面側では圧力面側 の水面が負圧面より高くなり水面の波が発生する．このため失速後の特性は変化が大きいと考えられる．また口 一ル角 $\phi$ が 0 でない状態では水中にある羽根面は長方形でなく上底長さと下底長さが刻々と変化する台形である. さらにロール角 0 の真下付近のロール角速度は大きく, 羽根反転過程ではロール角速度は 0 に近い. したがって 定常特性を用いること自体が近似である. 本解析は可能性を検討している段階のため高い精度の揚力・抗力特性

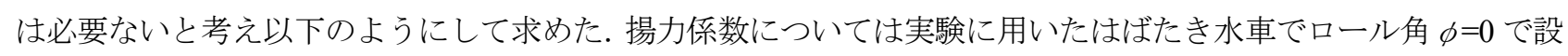
定ヨー角 $\theta_{0}$ を $30[\mathrm{deg}], 40[\mathrm{deg}]$ として測定したトルクの值から揚力係数 $C_{L}$ を求めた. 実験の結果では図中( Blade : $C_{L}$ (experiment) )のような結果を示した。この值を考慮し解析に使用する揚力係数 $C_{L}$ は図中( Blade： $C_{L}$

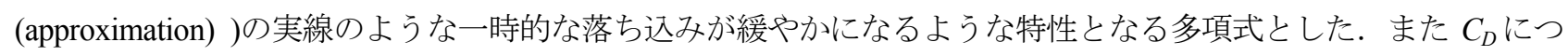
いては本研究では実験的検討を実施できなかったので文献(7)と同じ值を使用し式(8), 式(9)で表した.

$C_{L}=J+K \cdot i+L \cdot i^{2}+M \cdot i^{3}+N \cdot i^{4}$

$C_{D}=P+Q \cdot i+R \cdot i^{2}$

ここに

$J=-3 \times 10^{-12} \quad K=0.15 \quad L=-5.5 \times 10^{-3} \quad M=7.5 \times 10^{-5} \quad N=3.5 \times 10^{-7}$

$P=1.3 \times 10^{-2} \quad Q=1.37 \times 10^{-3} \quad R=6.51 \times 10^{-4}$

である. 表 1 の平均角速度を用いて計算した羽根スパン中央の平均入射角を図 7 中に示す. NACA0012 の特性 (7) をそのまま用いるより近似度を高めていると考える. 


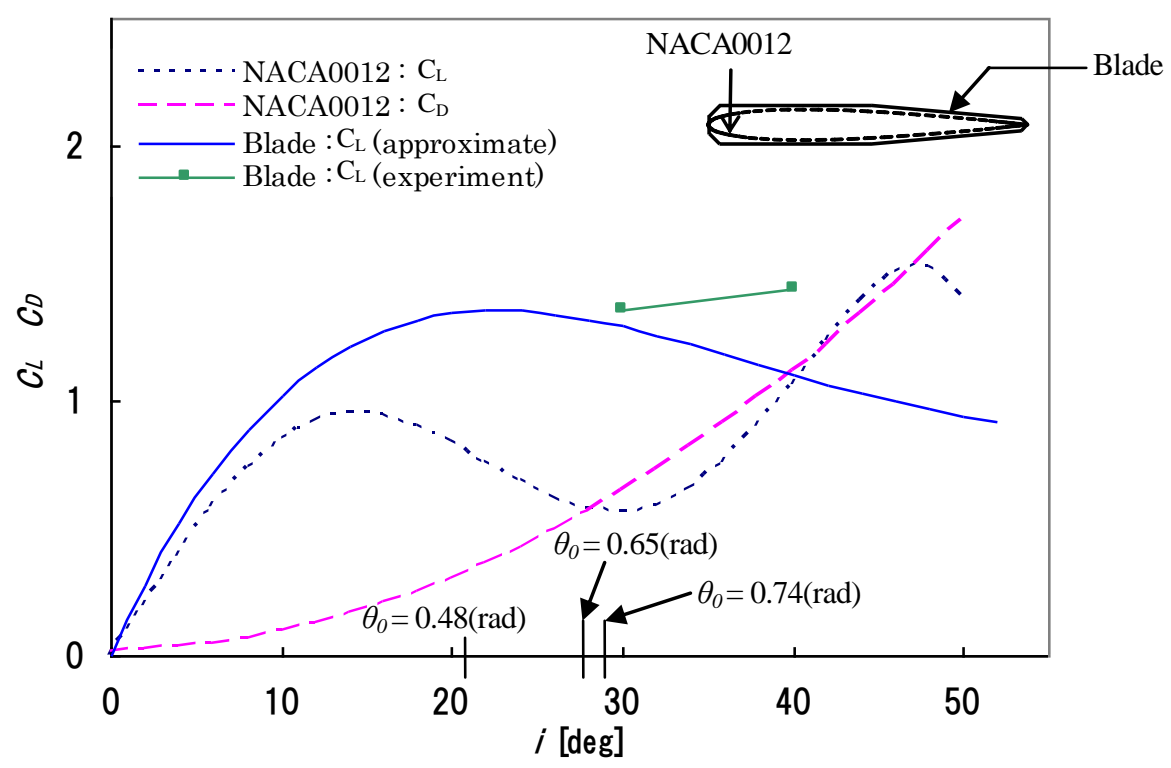

Fig.7 Fluid dynamic characteristics of blade

\section{$4 \cdot 3$ ヨ一角反転解析モデルの改良}

解析モデルでは 1 往復の運動に要する時間に対してヨー角が反転寸る時間の割合が小さく無視できるとしてい る. 最初の解析モデル(6)ではロール角速度が “0”(ロール角の絶対值が最大のとき)でヨー角を瞬間的に反転させ るものとしていた，本研究では羽根ヨ一角反転は前回と同じく瞬間的に行われるが，羽根が発生する流体力の羽 根支持軸周りのモーメントが重力のモーメントより小さくなったとき反転が起こるとして力の平衡の考えを取り 入れた。ヨー角 $\theta$ は

$\theta=\theta_{0} \times \operatorname{Sign}\left\{\frac{1}{2} \cdot \rho \cdot V^{2} \cdot C_{t} \cdot S \cdot G l \cdot \operatorname{Sign}\left(\frac{d \phi}{d t}\right)-M_{b l d} \cdot g \cdot G \cdot \sin (\phi) \cdot \cos \left(\theta_{0}\right)\right\} \quad \cdots(10)$

で表す. 中括弧内が正の場合は $+\theta_{0}$, 負の場合は一 $\theta_{0}$ となる. 中括弧内の第一項目 $C t$ は羽根反転時の流体力係数, $G l$ は羽根の流体力中心 (前縁から四分の一弦長位置と仮定) と羽根支持軸中心の間の距離 $\left(20.25 \times 10^{-3}[\mathrm{~m}]\right)$ である. これらの積は流体力が発生する支持軸周りのモーメントである. ヨー角が反転する状態ではロール角速度は小さ いから羽根への入射角は設定ヨー角である $\theta_{0}$ とおくことができる. このときの流体力の係数は

$C_{t}=\left(C_{L} \cos \theta_{0}+C_{D}\left|\sin \theta_{0}\right|\right)$

と表すことができる.

式(10)の，中括弧内第二項目は支持軸周りの重力による反転モーメントの項である. ロール角増加に伴う羽根 の水面上への露出による浮力の減少も考慮して，羽根を反転させようとする質量を

$M_{\text {bld }}=\left\{B \cdot\left(r_{2}-r^{\prime}\right)-S\right\} \cdot T_{h} \cdot \rho_{2}+S \cdot T_{h} \cdot \rho^{\prime}$

で表現した. 式中の記号はそれぞれ $B:$ 弦長 $(0.095[\mathrm{~m}]), r_{2}$ : 出力軸から羽根先端までの距離 $(0.265[\mathrm{~m}]), r^{\prime}:$ 出力 軸から水面までの距離 $(0.165[\mathrm{~m}]), T_{h}$ : 羽根厚さ $\left(12 \times 10^{-3}[\mathrm{~m}]\right), \rho_{2}$ : 羽根材料の密度 $\left(1400 \mathrm{~kg} / \mathrm{m}^{3}\right), \rho$ ' : 羽根と水 の密度差 $\left(400 \mathrm{~kg} / \mathrm{m}^{3}\right), G$ は羽根支持軸から羽根断面面積中心までの距離 $\left(\left(15.6 \times 10^{-3}[\mathrm{~m}]\right)\right.$ である. 


\section{$4 \cdot 4$ 解析の結果と検討}

実験值と解析值を比較するにあたり，5 往復の周期が実験值と合うようにパラメータを変化させた．当初の解 析(6)(表 2 の Original(ref.(6))で示す行の值)では本来一定值である $\Delta m$ を表 2 に示すようにそれぞれ $0.23 ， 0.0525$, 0.01 と変化させており, $\Delta m$ という荷重で周期を調節しているように見える. しかしこれは物理的に正しくない.

Table 2 Comparison of using parameter between original and improved analysis

\begin{tabular}{c|l|c|c|c}
\hline \multicolumn{2}{|c|}{$\theta_{0}[\mathrm{rad}]$} & 0.48 & 0.65 & 0.74 \\
\hline \multirow{3}{*}{$\Delta m \quad[\mathrm{~kg}]$} & Original (ref. (6)) & 0.23 & 0.0525 & 0.01 \\
\cline { 2 - 5 } & Improved & \multicolumn{3}{|c}{0.02} \\
\hline \multirow{3}{*}{$t_{5}[\mathrm{~s}]$} & Experiment & 33 & 24.2 & 18.5 \\
\cline { 2 - 5 } & Original (ref. (6)) & 32 & 24 & 21 \\
\cline { 2 - 5 } & Improved & 33 & 24 & 18.5 \\
\hline \multirow{2}{*}{$T_{\text {con }}$} & Original (ref. (6)) & 0.03 & 0.05 & 0.01 \\
\cline { 2 - 5 } & Improved & 0.0267 & 0.024 & 0.019 \\
\hline
\end{tabular}

また $\theta_{0}=0.74[\mathrm{rad}](42.5[\mathrm{deg}])$ ではこれ以上の周期の一致度の改善をすることができなかった. 本研究ではカウンタ 一ウエイトと羽根を含めた出力軸から下部の実際の質量の差を測定してこの值(約 $0.04 \mathrm{~kg}$ )を出力軸中心からの距 離を考慮して $\Delta m=0.02 \mathrm{~kg}$ と設定した. この值を一定とし制動力を表す $T_{\text {con }}$ (トルク係数)を変化させて解析した. その結果，すべてのヨー角で周期は実験值とほとんど一致させることができ物理的な矛盾をひとつ解決すること ができた.

図 8 に解析結果のグラフの一例を示す. 解析の流速は実験值と同じ $U=0.27[\mathrm{~m} / \mathrm{s}]$ とした. (1)実線がロール角 $\phi$, (2)点線がロール角速度 $d \phi / d t$, (3)破線がヨー角 $\theta$ を示している. $\phi$ の最大值, 最小值付近の時刻で $\theta$ が変化して いる点は，実際の現象を再現している．また表 1 の実験值から算出した平均ロール角速度 $\omega_{m}$ を図中の一点鎖線 で示寸. 実験值は解析で求めた $d \phi / d t$ の絶対值平均の 2 倍以上あることが明白で, 定量的な一致は十分でない. このため最大ロール角 $\Delta \phi$ とトルク $T$ について比較する.

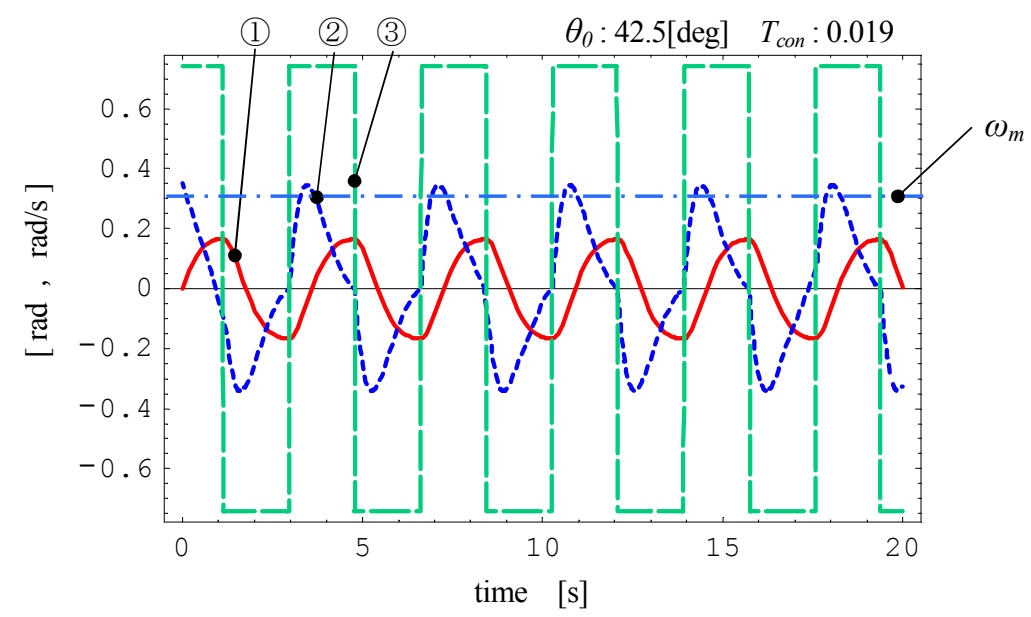

Fig. 8 Result of analysis in each yaw angle

図 9 に実験值, 改良前, 改良後の $\Delta \phi$ の比較のグラフ, 図 10 にトルク $T$ の比較のグラフを示す. $\Delta \phi$ はロー ル角の最大值, トルク $T$ は $d \phi / d t$ の最大值と $T_{c o n}$ の積であり, 実験でのばね秤を用いて測定したトルクの最大值 に対応させてある。 


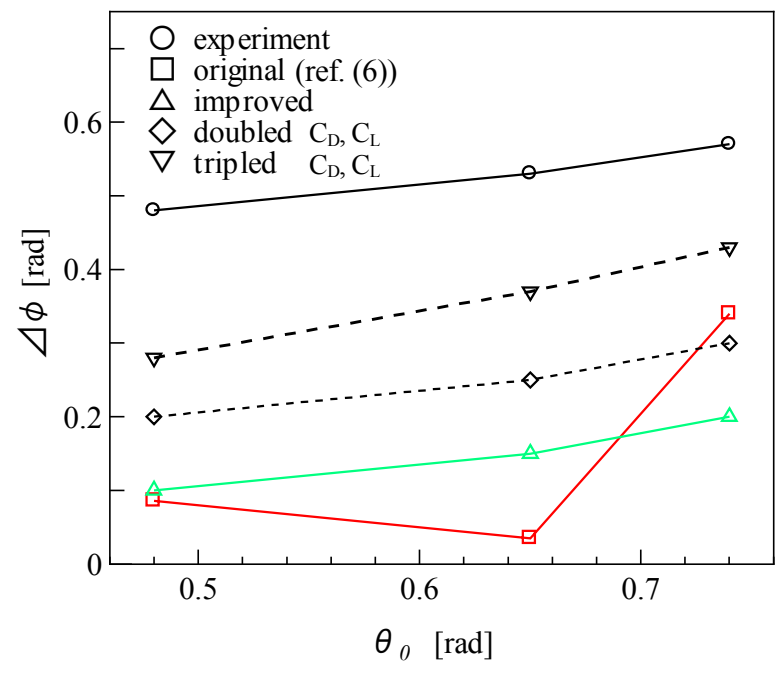

Fig.9 Comparison of roll angle between experiment and analysis

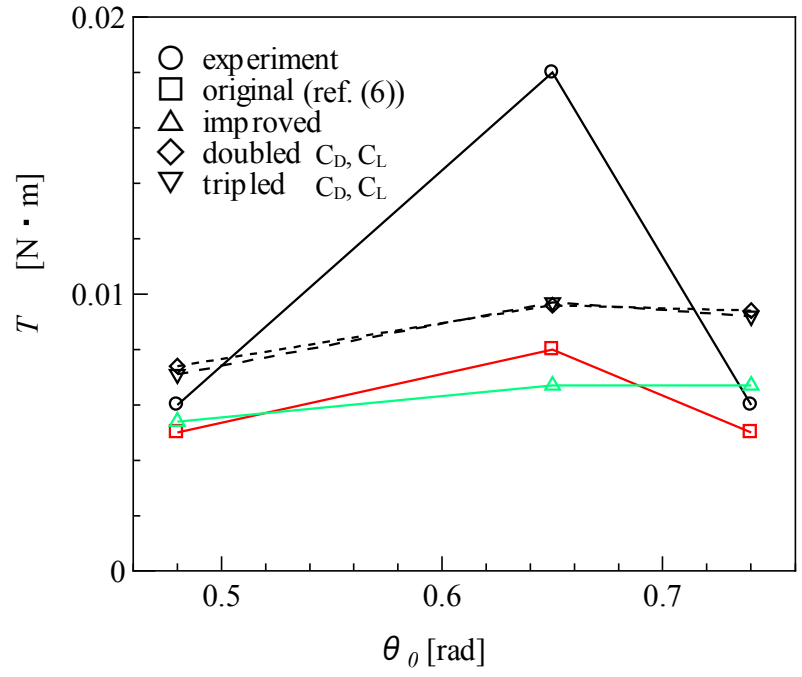

Fig.10 Comparison of torque between experiment and analysis in

図 9 によれば, 改良前(6) と比較して $\theta_{0}=0.48[\mathrm{rad}](27.5[\mathrm{deg}])$ では違いが小さいが, $\theta_{0}=0.65[\mathrm{rad}](37.5[\mathrm{deg}])$ では $\Delta \phi$ が大幅に増加した． $\theta_{0}=0.74[\mathrm{rad}](42.5[\mathrm{deg}])$ では逆に低下している．改良前，改良後ともに実験值との差は大きい が，実験值の $\Delta \phi か ゙ ~ \theta_{0}$ とともに増加している傾向は再現できるようになった．このことは羽根反転モデルの改良 による物理的矛盾解決の効果と考える. 図 10 のトルクの解析值については目立った改善は見られていない. この ことから本解析に用いた揚力係数, 抗力係数の值(図 7)が実際より小さいためと考え, 試みとして羽根の揚力係数, 抗力係数を 2 倍, 3 倍として解析した結果を図中の点線と破線で示す. ロール角 $\Delta \phi$ は揚力係数, 抗力係数が大 きくなるにつれすべてのヨー角で改善する傾向にある. しかし実験值との差は依然として大きい. またトルクの 解析值はすべてのヨー角で改善しているが $\theta_{0}=0.74[\mathrm{rad}](42.5[\mathrm{deg}]) \theta_{0}=0.47[\mathrm{rad}](27.5[\mathrm{deg}])$ では実験值より結果が大 きくなっている．トルクの解析值は揚力係数，抗力係数を増加させなくとも一部の值を除き解析結果と実験值は 比較的近くなっていること，また羽根の揚力特性曲線は一部のヨー角では揚力の測定結果を考慮し決定している ことから流体力の極端な過小評価は考えにくい. このことからロール角の実験值と解析值の差は羽根の流体力学 的特性以外に原因があると考えられる．そこで実際の羽根反転運動を観察し考察した.

\section{$4 \cdot 5$ 羽根反転の動作の考察}

\section{$4 \cdot 5 \cdot 1$ ヨ一角反転の動作の考察}

ヨー角反転を決定している式(10)では支持軸周りの羽根重量によるモーメントが羽根にかかる流体力により発 生するモーメントを超えると反転する. 反転時間は往復運動の時間に比べて小さいものとしてこれを考慮してい ない．しかし運動中は支持軸周りの慣性があり反転が開始した時点でもロール角は増大し続けること，また流れ の抵抗を受けることで反転にはある程度の時間を要することが考えられる.図 11 に羽根の反転運動の過程を示す。 (1)では羽根は真下にあり水流に対してヨー角がついておりロール運動している.このとき羽根はほぼ全体が水に 浸かり揚力を発生している. (2)ではロール角が次第に大きくなるにつれ羽根が水から露出している. (3)ではロー ル角が増加しつつ, 羽根が反転を始めた状態である. (4)で反転した羽根は設定ヨー角まで達すると逆方向に揚力 を発生し反対方向にロール運動する．このように反転時にロール角の変化とヨー角の変化がロール角最大付近で 並行して起こる. したがってヨー角の反転が瞬時に起こるとした式(10)に代わり羽根ヨ一角の時間変化に関する 微分方程式を式(2)と連立させることで実験值との一致度を改善できると考えられる.

\section{$4 \cdot 5 \cdot 2$ 反転前後の流れの考察}

図 11 (2) は反転を起こす直前の羽根の様子である. 羽根の水面上の部分が大きく, 水中の前縁の長さが後縁よ り長い.このことと 4.2 節で触れた水中の先端側の翼端渦の影響と, 水面側では圧力面側の水面が負圧面より高 
くなることの影響が重なり，揚力が一時的に増加することも考えられる. 式(8), (9)で与えた揚力係数曲線, 抗力 係数曲線ではこの点が考慮されておらず，このこともロール角，トルクの解析值が実験值と一致しない原因と考 えられる。

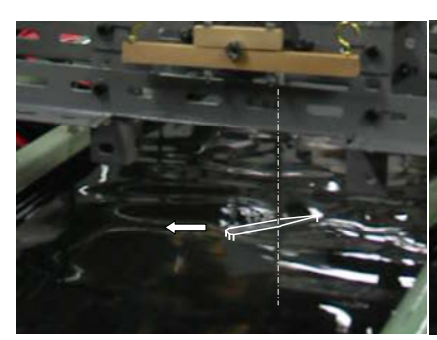

(1)

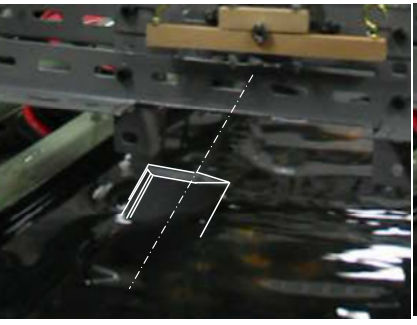

(2)

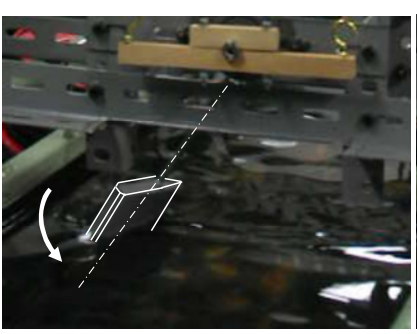

(3)

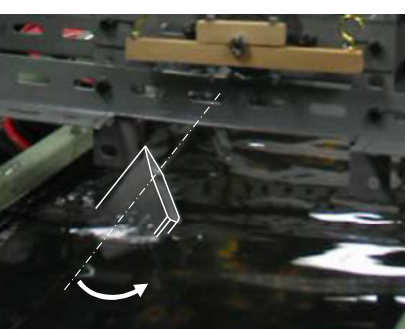

(4)

Fig.11 Process of blade turning

\section{5. ヨ一角設定機構の改良と河川実験}

\section{$5 \cdot 1$ ヨ一角設定機構の改良}

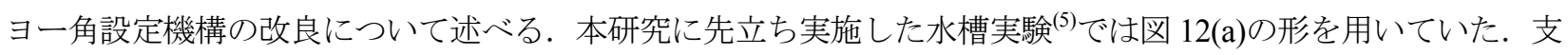
持軸に組み込まれた制御棒をスライドさせヨーリミッタに設けられた窪みにはめ込むことにより固定していた. ロール角増大に伴いヨーリミッタ上部に取り付けられた錘がロール方向と逆方向に傾き, 洼みから制御軸が外れ て羽根は逆方向に反転した. しかしこの機構では流速が大きい場合, 周期が早くなることでヨーリミッタによる 制御軸の固定・開放の一連の動作が不安定であった．本研究では当初から河川実験を計画していたため，図 4 の 水槽実験から図 12 (b)のように制御棒ストッパを用いて運動時のヨー角の最大角のみを制限するような機構にし た.これにより流速が大きい場合にも確実な反転動作がおこなえるようになった.

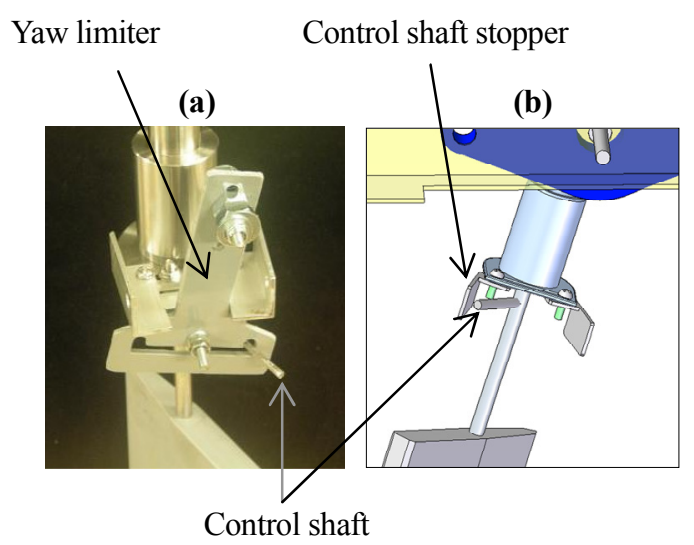

Fig.12 Improvement of yaw setting part

\section{$5 \cdot 2$ 河川での実験}

河川での実験の目的は, 波などがあり流れが不均一な場合にも, はばたき水車の動作と動力の取り出しが可能 であるかどうかを確認することにある．実験にあたり装置を大型化して出力の確認を容易におこなえるようにし た. 図 13 に実験装置を示寸. 出力軸からの動力は歯車により二段増速させ, さらに増速ギア付き直流モータを発 電機として使用した. 出力軸からの合計増速比は約 270 である. 図 14 に回路図を示す. はばたき水車は往復運動 により動力を発生するので往復の始点と終点では動力を発生せず，また運動の方向が変化することから電流の方 向, 大きさが変化することとなる. このため電力は接続された電流計, 電圧計の瞬間的な最大值 $I, V$ を読取り, 
式(13)により計算した．また回路図の負荷は豆電球を用いた．実験の様子を図 15 に示寸．実験は北海道函館市に ある二級河川松倉川水系松倉川で実施した．装置は両側にフロートを取り付け水面上に浮かせ，これを人が支え ることにより水面からの高さを調節している.

$P=I \times V$

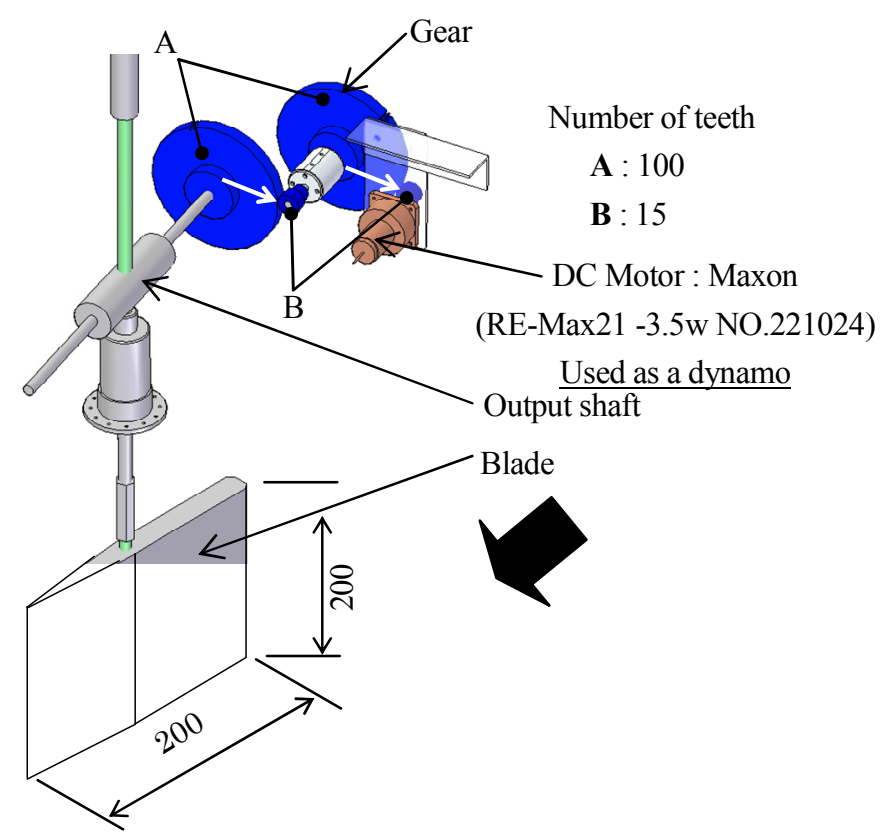

Fig.13 Experimental apparatus at River Matsukura
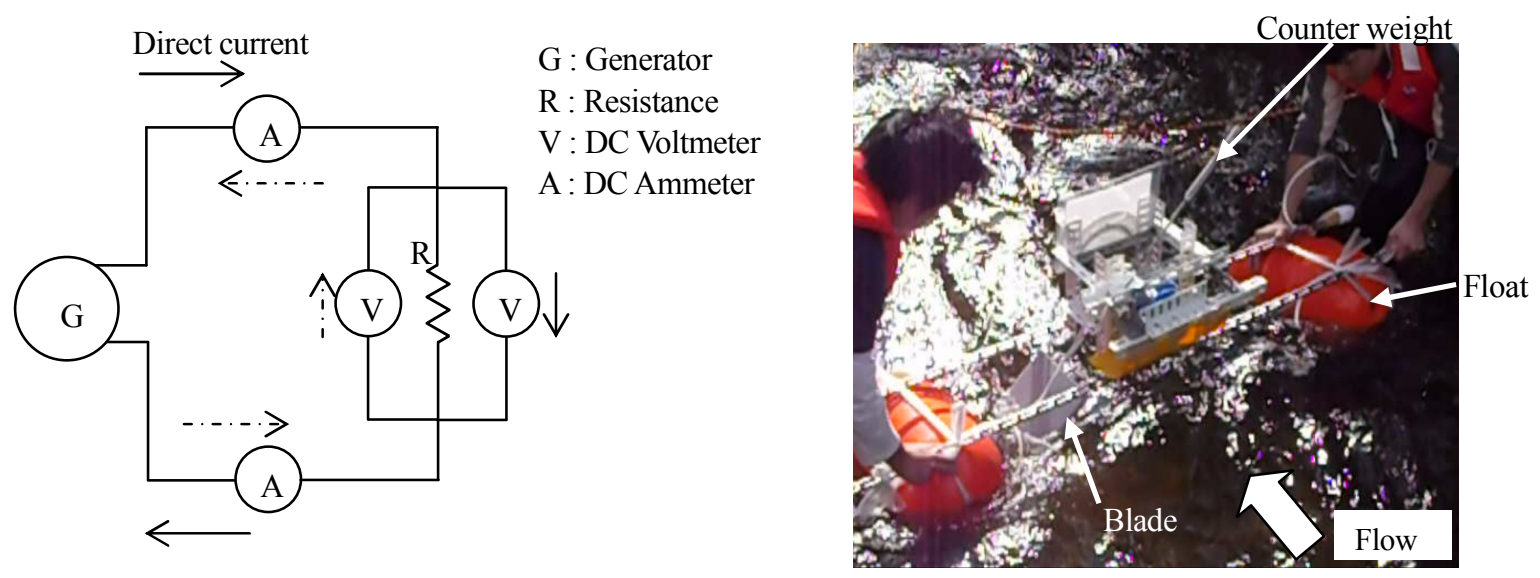

Fig.14 Circuit diagram

Fig.15 Experiment by using enlarged blade at River Matsukura

Table 3 Result of experiment

\begin{tabular}{c|c|c|c|c}
\hline Flow velocity $[\mathrm{m} / \mathrm{s}]$ & $\begin{array}{c}\text { Time of one cycle } \\
{[\mathrm{s}]}\end{array}$ & Current [mA] & Voltage [v] & Output [w] \\
\hline 0.86 & 2.85 & 250 & 3.2 & 0.8 \\
\hline
\end{tabular}


表 3 に実験結果を示寸，負荷として取り付けた豆電球が点灯し，出力を取り出せることを実証できた.

\section{$5 \cdot 3$ 水槽実験との比較と検討}

表 4 に水槽実験と河川実験の結果の比較を示寸. Cp は出力係数, Reはレイノルズ数, Fr はフルード数で ある. 上流側の水面の波の影響などがあり河川実験では性能の低下を予測したが, ロール角 $\Delta \phi$, 平均ロー ル角速度 $\omega_{m}, C p$ ともに水槽実験を上回っている. このことは羽根を駆動する流体力が羽根寸法, 流速の増 大以上に大きいことを示している.そこでReとFrに着目すると, どちらも河川実験のほうが大幅に大きい. $R e の$ 差は羽根表面の摩擦やはく離の様相の違いを示している. また河川実験では羽根前縁から生じる波が 目立って高く, Frの違いの影響が大きいことを示している. はばたき水車の研究開発を進めるにあたり相 似則についても注目する必要がある.

Table 4 Compearison between water channel experiment and river experiment

\begin{tabular}{|c|c|c|c|c|c|c|c|}
\hline Experiment & $\begin{array}{c}\text { Flow velocity } \\
{[\mathrm{m} / \mathrm{s}]}\end{array}$ & $\begin{array}{c}\theta_{0} \\
{[\mathrm{rad}]}\end{array}$ & $\begin{array}{l}\Delta \phi \\
{[\mathrm{rad}]}\end{array}$ & $\begin{array}{c}\omega_{m} \\
{[\mathrm{rad} / \mathrm{s}]}\end{array}$ & $C p$ & $\mathrm{Re}$ & $\mathrm{Fr}$ \\
\hline \multirow{3}{*}{$\begin{array}{l}\text { Water } \\
\text { channel }\end{array}$} & \multirow{3}{*}{0.27} & 0.74 & 0.567 & 0.306 & 0.019 & \multirow{3}{*}{$2.6 \cdot 10^{4}$} & \multirow{3}{*}{0.28} \\
\hline & & 0.65 & 0.524 & 0.217 & 0.042 & & \\
\hline & & 0.48 & 0.48 & 0.145 & 0.010 & & \\
\hline River & 0.86 & 0.7 & 1.05 & 0.735 & 0.063 & $1.7 \cdot 10^{5}$ & 0.61 \\
\hline
\end{tabular}

$C p, \operatorname{Re}, \mathrm{Fr}$ の定義は以下の通りである.

$$
C p=\frac{\text { Power }}{\frac{1}{2} \cdot \rho \cdot U^{3} \cdot S_{0}}
$$

$S_{0}$ は习习习根面積, 河川実験の出力の值は発生電力, 水槽実験では測定トルクと平均ロール角速度の積とした.

$$
R e=\frac{U \cdot B}{v}
$$

$B$ は羽根弦長, $v$ は水の動粘度で $1 \cdot 10^{-6} \mathrm{~m}^{2} / \mathrm{s}$ を用いた.

$$
F r=\frac{U}{\sqrt{B \cdot g}}
$$

$g$ は重力加速度である.

\section{6. 実用化の可能性について}

”はばたき水車”を用いた水流からのエネルギの取出しは，ダムなどの貯水施設を建設する必要がなく環境への 負荷が小さい，自然の流れを利用する場合，装置に上流から異物が流れ込むことや魚類に対して影響を与える可 能性がある.この点で ”はばたき水車”は一枚の羽根により流れからエネルギを取出す方式をとっていることで流 れをふさぐことが少ないことが利点として考えられる. しかし実用化を考えるには，機械的な耐久性・信頼性な どの問題を含めた検討を行う必要がある. 


\section{7. おわりに}

水流方向の軸回りに往復回転運動する羽根で動力を取り出し, 往復運動の始点と終点では重力を利用して羽根 角度を変化させる簡単な機構を備えた”はばたき水車”について一次元解析による出力トルク，ロール角の予測の 試みと，河川での発電実験を実施し以下の結論を得た。

(1) 羽根支持軸周りの力の釣り合いによって，ヨー角を決定する式を導いたうえロール角に関する運動方程式を 数值積分し，周期が実験值と一致するように制動のパラメータを変化させた．最大ロール角の解析値は，実 験值より小さく、定性的な一致にとどまった．一致度の向上には羽根に作用する流体力の把握とともにヨー 角に関する運動方程式を連立させて解析して検討する必要がある.

（2) 羽根反転動作が円滑におこなえるようなヨー角設定機構を使用し，実際の河川で発電することができた.

\section{謝 辞}

本研究の実施にあたり函館工業高等専門学校地域連携協力会, 函館工業高等専門学校技術教育支援センタ(実習 工場)のご支援とご協力をいただいたことを付記するとともに, 松倉川での実験に参加した函館工業高等専門学校 機械工学科学生 藤谷剛君に謝意を表します.

\section{文 献}

(1) 中里勝芳, “中里研究室”, <http://w3p.phys.chs.nihon-u.ac.jp/ nakazato/>, (参照日 2011 年 02 月 16 日)

(2) Bradley, J.S., Stephan, L., Franz, S.H., and Michel, S.T., "Energy Extraction Trough Flapping Foils", ASME 27 $7^{\text {yh }}$ International conference on Offshore Mechanics and Arctic Engineering, OMAE2008-58043, (2008), pp.389-395

（3）株式会社システック, 羽ばたき形風力発電機, 特願 2008-216932, (2008)

(4) 味戸真二, 石井勇気, 中川幸二, “摇動形水車の開発研究” , 日本機械学会北海道学生会第 35 回学生員卒業研究 発表講演会講演論文集, (2006), pp.186-187

（5）西口三津夫，中川幸二，“はばたき形水車の実験的検討”，日本機械学会北海道支部第 46 回講演会講演概要集, (2007), pp.77-78

（6）岩岸知崇，中川幸二，“はばたき形水車の出力予測の試み”, 日本機械学会北海道支部第 48 回講演会講演概要集, (2009), pp.43-44

(7) Fiedrich, W.R., AEROFOIL SECTIONS, (1961) p.247, Butterworths 